Vol. 11 (2002): 343-353.

\title{
Dissolved reactive phosphorus in runoff assessed by soil extraction with an acetate buffer
}

\author{
Risto Uusitalo and Håkan Jansson \\ MTT Agrifood Research Finland, Environmental Research, FIN-31600 Jokioinen, Finland, \\ e-mail: risto.uusitalo@mtt.fi
}

\begin{abstract}
Agronomic soil test phosphorus (STP) data is, in addition to fertility studies, increasingly utilised in environmental risk assessment. We compared relationships between soil P extracted by acid ammonium acetate (AAAc-P) and water-soluble $\mathrm{P}(\mathrm{Pw})$ in laboratory, and AAAc-P and dissolved molybdatereactive $\mathrm{P}(\mathrm{DRP})$ in field runoff. The laboratory study suggested a close relationship $\left(\mathrm{R}^{2}=0.87, n=\right.$ 64) between AAAc-P and soluble $P$ concentration in 1:100 (w/v) soil-to-water extracts, described by a linear equation: $\mathrm{Pw}\left(\mathrm{mg} \mathrm{l}^{-1}\right)=0.021 \times \mathrm{AAAc}-\mathrm{P}\left(\mathrm{mg} \mathrm{l}^{-1}\right.$ soil $)-0.015\left(\mathrm{mg} \mathrm{l}^{-1}\right)$. In Lake Rehtijärvi cathcment, dominated by clayey soils, the AAAc-P content of field Ap horizon in a similar manner influenced the flow-weighted DRP concentration in surface runoff and drainflow: a $1 \mathrm{mg} \mathrm{l}^{-1}$ increase in soil AAAc-P corresponded to 0.015 and $0.018 \mathrm{mg} \mathrm{l}^{-1}$ increase in surface runoff and drainflow DRP, respectively. When the AAAc-P vs. Pw relationship obtained in the laboratory test was used to predict the average DRP concentration in edge-of-field runoff, the precision of the DRP estimates inferred from STP data was in $95 \%$ of the cases $\pm 0.10 \mathrm{mg} \mathrm{l}^{-1}$. In the L. Rehtijärvi catchment, $50 \%$ of the diffuse DRP loading risk was assigned to an area that corresponded to less than $20 \%$ of the fields and the situation may be similar in the national scale.
\end{abstract}

Key words: eutrophication, phosphorus, runoff, soil testing, catchment studies

\section{Introduction}

Even though agronomic soil $\mathrm{P}$ tests have not been designed for an assessment of P loss capacity of a soil, soil test P (STP) data have been found to serve as an indicator for elevated $\mathrm{P}$ loss risk (Heckrath et al. 1995, McDowell and Sharpley 2001). Likely being the most accessible and economic means for this purpose, STP is a conven- ient input parameter to be included in models aiming to predict - not only elevated P loss risks (Lemunyon and Gilbert 1993, Jokela et al. 1998, Gburek et al. 2000) - but also P concentration in runoff and $\mathrm{P}$ losses to surface waters (Tattari et al. 2001, Daly et al. 2002).

The agronomic soil test in use in Finland is based on extraction with an acidic ammonium acetate buffer (AAAc; $0.5 \mathrm{M}$ ammonium acetate and $0.5 \mathrm{M}$ acetic acid, $\mathrm{pH} 4.65$; Vuorinen and 


\section{Uusitalo, $R$. \& Jansson, $H$. Dissolved reactive $P$ in runoff}

Mäkitie 1955), an extractant quite similar to those used in the republic of Ireland (Morgan's test) and in some north-eastern states of the USA (Vermont 1 test). The acetate tests are related to the size of the easily soluble P pool in soil and they sensitively respond to soil $\mathrm{P}$ buffering (see Lee and Bartlett 1977, Kuo 1990). Because the most easily desorbable part of surface-adsorbed soil $\mathrm{P}$ likely determines the concentration of dissolved molybdate-reactive P (DRP) in runoff, acetate soil tests may be a theoretically sound option as environmental soil tests when DRP losses are concerned (see Magdoff et al. 1999). This is not necessarily the case with all soil tests, as many of them (e.g., Bray, Mehlich) are designed for estimation of (long-term) P supplying capacity of soils and lack sensitivity to $\mathrm{P}$ buffering by soils (see Holford 1980); therefore, the $\mathrm{P}$ pool extracted by these tests may rather refer to the potential for $\mathrm{P}$ release from eroded soil material.

When different soil tests have been compared, the acetate tests have been found superior to the stronger extractants when predicting water- or $\mathrm{CaCl}_{2}$-extractable $\mathrm{P}$ in soils from northeastern USA and Ireland (Magdoff et al. 1999, Maguire et al. 2001). Also in a field study, Turtola and Yli-Halla (1999) showed that average DRP concentration in surface runoff from a Spodosol amended with different amounts of slurry and mineral fertilisers very sensitively followed the changes in soil AAAc-P, more so than the changes in bicarbonate-extractable $\mathrm{P}$, the estimate of $\mathrm{P}$ saturation (ratio of the sum of $\mathrm{NH}_{4} \mathrm{~F}-\mathrm{P}$ and $\mathrm{NaOH}-\mathrm{P}$ to the sum of oxalate-extractable $\mathrm{Al}$ and $\mathrm{Fe}$ ), or anion exchange resin-extracble $\mathrm{P}$.

Were we able to reliably estimate DRP concentration in runoff by using soil AAAc-P content, the data from a limited number of experimental fields could possibly be complemented by more geographically representative data, e.g., when the impacts of different management practises to DRP losses from agricultural fields are studied. In Finland, all of the farmers that are committed to the Agri-Environmental Programme (AEP; for an overview of the Finnish AEP, see Valpasvuo-Jaatinen et al. 1997) have to test their soils for P every fifth year to avoid excessive $\mathrm{P}$ fertilization. As a result of the commitment to the AEP, up-to-date AAAc-P data exist for about $90 \%$ of the fields of the country. Whether it is possible to utilise this data in directing different management options in a costeffective manner to control eutrophication is one question to be evaluated.

We studied the relationship between AAAcextractable $\mathrm{P}$ and the concentration of soluble $\mathrm{P}$ in a water extract (Pw, according to Yli-Halla et al. 1995 suited for approximation of average DRP concentration in surface runoff) in laboratory using 64 soils sampled from the Kokemäenjoki river basin, southern Finland. Then, we tested the feasibility of this relationship as a predictor for DRP concentration of surface and subsurface runoff at Lake Rehtijärvi catchment (south-western Finland). We also assessed the frequency of the fields with high $\mathrm{P}$ loss potential in the L. Rehtijärvi cathcment, and made a remark on the situation in the scale of whole Finland.

\section{Material and methods}

\section{Study sites and soil analyses}

For the laboratory study, mineral soil samples weighing about $5 \mathrm{~kg}$ each were taken from catchments of five lakes within a $10,000 \mathrm{~km}^{2}$ area of the upper Kokemäenjoki river basin at the Häme region, southern Finland (Fig. 1). The samples represented a variety of textural classes, soil $\mathrm{pH}$ and organic matter content (Table 1). Of the total of 64 samples taken, 59 were from agricultural land (arable fields and pastures), and five from non-cultivated areas (forest floor and setaside areas). At the sites where the depth of the latest primary tillage was visible, the sampling depth was the depth of cultivation (mostly 0-20 $\mathrm{cm}$, because sampling was mostly done on ploughed soil); at the other sites, the sampling depth was $0-5 \mathrm{~cm}$. 
Vol. 11 (2002): 343-353.

The site of the field survey was the Lake Rehtijärvi catchment (Fig. 1) at Jokioinen community, south-western Finland. Soils of this area have been classified and detailed by Yli-Halla and Mokma (2001). The agronomic soils of the catchment, 225 ha in total, were mostly tiledrained Typic Cryaquepts, with some Aquic Dystrocryepts according to the US Soil Taxonomy (Soil Survey Staff 1998). The soils were predominantly clayey in texture (Table 2) and the fields were mostly used for growing cereals, especially barley (Hordeum vulgare). All of the fields of the catchment were sampled by taking 10-12 subsamples at the depth of the latest cultivation (mostly $0-20 \mathrm{~cm}$, as almost all of the fields were annually ploughed at about $20 \mathrm{~cm}$ ) which were combined to make one representative 0.5-litre soil sample for each field hectare.

The soil samples were dried at $35-40^{\circ} \mathrm{C}$, ground to pass through a $2-\mathrm{mm}$ sieve, and homogenised. Concentration of total $\mathrm{C}$ was determined using a LECO (St. Joseph, MI, USA) CN2000 analyser. Soil pH was measured in 1:2.5 $(\mathrm{v} / \mathrm{v})$ soil-water suspension and soil texture was assessed by fingers.

In the AAAc extraction (Vuorinen and Mäkitie 1955), $25 \mathrm{ml}$ air-dry soil was shaken endover-end $(37 \mathrm{rpm})$ with $250 \mathrm{ml}$ of AAAc solution $\left(0.5 \mathrm{M} \mathrm{CH}_{3} \mathrm{COONH}_{4}\right.$ and $0.5 \mathrm{M} \mathrm{CH}_{3} \mathrm{COOH}$, $\mathrm{pH} 4.65$ ) for $30 \mathrm{~min}$, whereafter the suspension was passed through a S\&S $589^{3}$ blue ribbon pa-

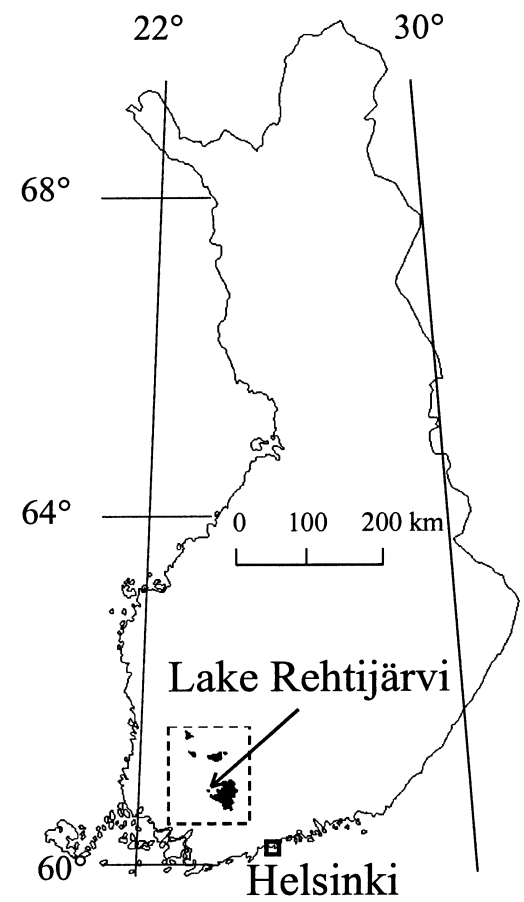

Fig. 1. The shaded areas represent the catchments of the lakes where the soils for this study were sampled.

per (Schleicher \& Schuell, Dassel, Germany), and the filtrate analysed for $\mathrm{P}$ using stannous chloride reduction of the phospho-molybdate complex. The 64 Kokemäenjoki basin soils were extracted with duplicates, whereas the soils sampled from the L. Rehtijärvi catchment were ana-

Table 1. Properties of the Kokemäenjoki basin soils studied, grouped according to texture. Numbers are median values, followed by the range in parentheses.

\begin{tabular}{|c|c|c|c|c|c|c|c|c|}
\hline Soil group & $n$ & Texture & $\mathrm{pH}\left(\mathrm{H}_{2} \mathrm{O}\right)$ & $\begin{array}{c}\text { Org. C } \\
\%\end{array}$ & $\begin{array}{l}\text { Olsen-P } \\
-\mathrm{mg} \mathrm{k}\end{array}$ & $\begin{array}{r}\mathrm{Pw}_{1: 100} \\
\mathrm{~kg}^{-1} \text { soil }\end{array}$ & $\begin{array}{l}\text { AAAc-P } \\
-\mathrm{mg}\end{array}$ & $\begin{array}{l}\text { Mehlich 3-P } \\
1^{-1} \text { soil }\end{array}$ \\
\hline Fine-textured & 18 & $\mathrm{c}, \mathrm{sic}$ & $6.0(5.2-6.9)$ & $3.8(2.0-10)$ & $41(8-91)$ & $13.4(1.2-74)$ & $7(2-26)$ & $58(14-155)$ \\
\hline Medium-textured & 25 & $\mathrm{scl}, \mathrm{cl}, \mathrm{sicl}$ & $5.8(5.2-7.2)$ & $3.7(1.5-14)$ & $32(14-90)$ & 11.3 & $6(3-29)$ & $63(9-174)$ \\
\hline Coarse-textured & 21 & 1s, sl, scl, 1, sil & $5.7(4.9-6.5)$ & $3.1(1.2-19)$ & $34(6-95)$ & $12.5(0.2-62)$ & $7(2-32)$ & $100(4-416)$ \\
\hline All soils & 64 & & $5.8(4.9-7.2)$ & $3.6(1.2-19)$ & $34(6-95)$ & $12.6(0.2-74)$ & $7(2-32)$ & $61(4-416)$ \\
\hline
\end{tabular}

Textural classes: c, clay; sic, silty clay; scl, sandy clay loam; cl, clay loam; sicl, silty clay loam; ls, loamy sand; sl, sandy loam; scl, sandy clay loam; 1, loam; sil, silt loam

Olsen-P: P extracted by $0.5 \mathrm{M} \mathrm{NaHCO}_{3}$, pH 8.5 (Kuo 1996)

Pw: water-extractable $P$

AAAc-P: $P$ extracted by ammonium acetate buffer

Mehlich 3-P: P extrcated by Mehlich 3 extractant (Mehlich 1984) 


\section{Uusitalo, $R$. \& Jansson, $H$. Dissolved reactive $P$ in runoff}

Table 2. Properties of the cultivated field area in the Lake Rehtijärvi catchment (total catchment area = 325 ha), as well as, the properties of the fields from which the sampled surface runoff and drainflow originated. Measured values are given as median values, with range (min-max) in parentheses.

\begin{tabular}{lccc}
\hline & $\begin{array}{c}\text { Fields of the Lake } \\
\text { Rehtijärvi catchment }\end{array}$ & $\begin{array}{c}\text { Surface runoff } \\
\text { source area }\end{array}$ & Drainflow source area \\
\hline Field area, ha & 225 & 69 & 137 \\
Fields with more than $30 \%$ clay & $88 \%$ & $89 \%$ & $93 \%$ \\
Ammonium acetate-extractable P, $\mathrm{mg} \mathrm{l}^{-1}$ soil & $3.6 \quad(1.3-66)$ & $3.1 \quad(1.3-19.8)$ & $4.4(1.4-19.8)$ \\
pH & $5.9(5.3-7.0)$ & $5.8(5.3-6.8)$ & $6.0(5.5-6.7)$ \\
Organic C, \% & $3.4 \quad(1.0-10.3)$ & $3.5(1.0-5.9)$ & $3.4(2.0-4.9)$ \\
Electrical conductivity, $\mathrm{mS} \mathrm{cm}^{-1}$ & $0.46(0.26-2.10)$ & $0.43(0.26-1.67)$ & $0.53(0.31-1.67)$ \\
\hline
\end{tabular}

lysed without replicates, as is done in routine soil testing. For quality control, every tenth sample was extracted with a duplicate and the results of the duplicate determinations were allowed to differ from each other $20 \%$ at maximum, or the batch in question reanalysed. Previously analysed samples were included in all test series, and the whole test series were reanalysed in case the difference of the results exceeded $20 \%$.

For 1:100 (w/v) water extraction of the 64 Kokemäenjoki basin soil samples, $1 \mathrm{~g}$ of air-dry soil was shaken end-over-end ( $37 \mathrm{rpm})$ in 100 $\mathrm{ml}$ deionised water for $18 \mathrm{~h}$, whereafter the suspension was passed through a $0.2-\mu \mathrm{m}$ Nuclepore (Whatman International, Maidstone, UK) polycarbonate filter. The phosphorus concentration in the filtrate was determined colorimetrically by the molybdate blue-ascorbic acid method (Murphy and Riley 1962). The water extraction was performed with triplicates.

\section{Runoff sampling and analyses}

At the L. Rehtijärvi catchment, sampling from field drains and open ditches was conducted at 90 sampling points during 1994-1996 (a part of the results obtained from this campaign has been published by Jansson et al. 2000). For the present study, the study area and the analyses results were later re-examined and all of the drains and ditches that were possibly influenced by household wastewater or leakage from manure stor- age, i.e., non-diffuse $\mathrm{P}$ sources, were carefully excluded. After the first selection, that excluded the sampling points located downstreams of cowsheds and piggeries, or that were known to receive septic tank effluents, further selection was done on the basis of chemical analyses. It was found (Jansson, unpublished data) that the concentrations of $\mathrm{Na}$ and $\mathrm{B}$ in filtered runoff samples were, especially at low-flow periods, higher in the wastewater-affected ditches than in those ditches that were known to carry only field and forest runoff. Presence of B as an indication of wastewater in field drains has earlier been used by Gardner et al. (2002). In the field runoff at the L. Rehtijärvi catchment, typically less than $6 \mathrm{mg} \mathrm{Na}^{-1}$ and less than $0.03 \mathrm{mg} \mathrm{B}^{-1}$ was measured. A drain or a ditch that could possibly be connected to a point-source (e.g., septic tank) was not taken into our comparison in case the concentrations of these tracers in any of the samplings exceeded $15 \mathrm{mg} \mathrm{Na}^{-1}$ or $0.1 \mathrm{mg} \mathrm{B}^{-1}$; maximum values measured in our original data set were $50 \mathrm{mg} \mathrm{Na}^{-1}$ and $0.5 \mathrm{mg} \mathrm{B} \mathrm{l}^{-1}$. Finally, data from 54 sampling points were found suitable for the present study.

Surface runoff samples $(0.51)$ were taken during two or three calendar years (1-7 samples per each ditch and year) as grab samples from 18 open ditches running along the fields studied. Water flow in the ditches at the time of samplings was approximated by calculating from flow velocity and water cross section. As well, water discharging from 36 subsurface drainage pipes was sampled (1-9 samples per each drain 
Vol. 11 (2002): 343-353.

and year, sample size 0.51 ); the flow was then assessed by measuring the discharge volume per second.

Concentrations of DRP and TP in runoff were analysed with the method of Murphy and Riley (1962) after filtration through a $0.4 \mu \mathrm{m}$ Nuclepore for DRP, and after peroxidisulphate-sulphuric acid digestion of an unfiltered subsample in an autoclave $\left(120^{\circ} \mathrm{C}, 30 \mathrm{~min}\right.$.) for TP. Particulate $\mathrm{P}(\mathrm{PP})$ was taken as the difference between TP and DRP. Total suspended solids (TSS) concentration was estimated by weighing the evaporation residue of a 50-100 $\mathrm{ml}$ subsample. The concentrations of individual samples were pooled to get an estimate of the mean flowweighted concentration in runoff within a calendar year. The flow-weighted annual concentrations of the (two or three) study years were then averaged over the years to be compared with the arithmetic mean AAAc-P of the source. The AAAc-P test value for which the comparison was made represented 1-13 field hectares, the median field size being 3.8 ha.

\section{Results}

For the 64 Kokemäenjoki basin soils, with variable physical and chemical properties (see Ta- ble 1) and soil $\mathrm{P}$ status ranging from 'poor' to 'high' according to the agronomic interpretation, the $\mathrm{P}$ concentration of the water extracts clearly increased with the AAAc-P concentration of the soils (Fig. 2). The relationship could be described by a linear equation where a $1 \mathrm{mg} \mathrm{l}^{-1}$ increase in soil AAAc-P concentration corresponded to a $21 \mu \mathrm{g}^{-1}$ (with a standard error, SE, of $1.0 \mu \mathrm{g}^{-1}$ and a probability-value less than 0.0001) increase in $\mathrm{P}$ concentration in the water phase and a constant term (y-axis intercept) having a value of $-15 \mu \mathrm{g}^{-1}$ (with a SE of $11 \mu \mathrm{g} \mathrm{l}^{-1}$ and a probability-value of 0.1863 ). This equation accounted for $87 \%$ of the variation in water-soluble $\mathrm{P}$ for these soils. Whether this pattern could be observed in field runoff, was then tested at the L. Rehtijärvi catchment.

The L. Rehtijärvi catchment soils containing the highest concentrations of AAAc-extractable $\mathrm{P}$ in the Ap horizon tended to produce runoff with the highest mean DRP concentrations in surface runoff (viz. water sampled from open ditches; Fig. 3) and drainflow (Fig. 4). The slope estimates of the least squares lines drawn in Fig. 3 and 4 were somewhat smaller than in the laboratory study, and similar to each other: a unit increase in soil AAAc-P corresponded to 15 and $18 \mu \mathrm{g} \mathrm{l}^{-1}$ (with standard errors, SE, of 1.5 and $2.7 \mu \mathrm{g} \mathrm{l}^{-1}$, respectively; probability-values less than 0.0001) increase in DRP for surface runoff
Fig. 2. Relationship between soil test $\mathrm{P}$ (AAAc-P) concentration and water-extractable $\mathrm{P}(\mathrm{Pw})$ for the 64 soils sampled in the Kokemäenjoki basin. The $\mathrm{x}$-axis error bars represent the range in duplicate AAAc-P determinations and the $y$ axis error bars represent standard deviation of the $\mathrm{P}$ concentration of the water extracts $(n=3)$.

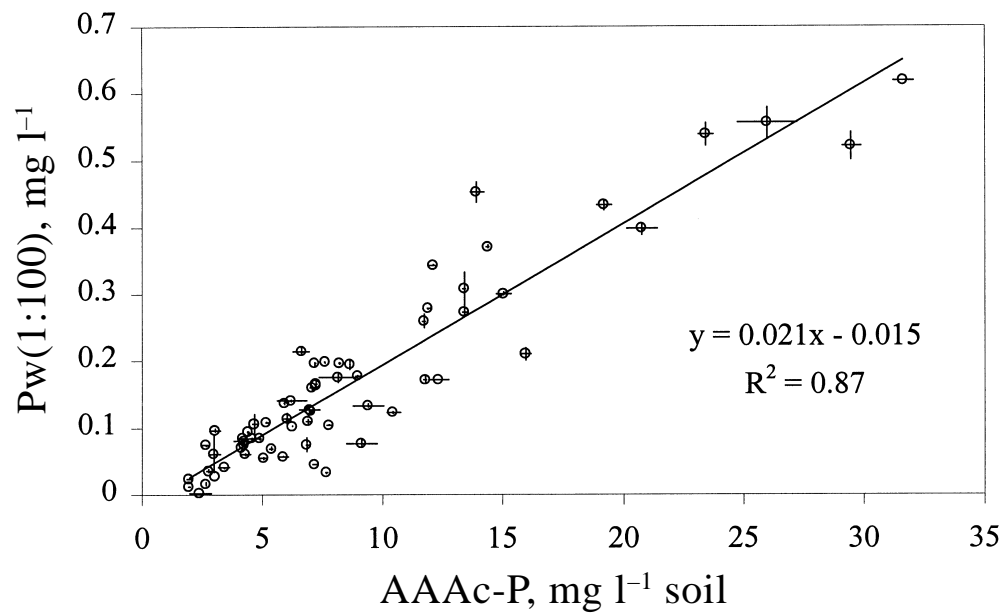


Uusitalo, $R$. \& Jansson, $H$. Dissolved reactive $P$ in runoff

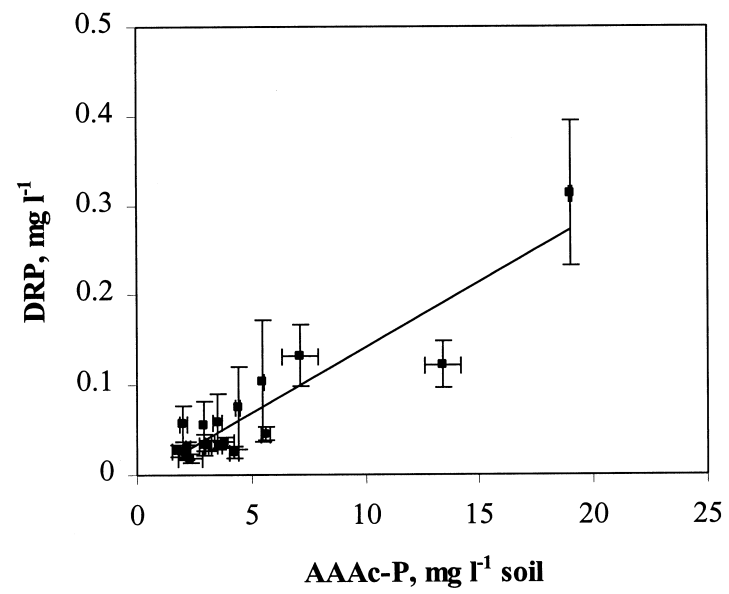

Fig. 3. Concentration of dissolved reactive $P(D R P)$ in surface runoff at the L. Rehtijärvi catchment as a function of soil test $\mathrm{P}$ concentration (AAAc-P) in phough-layer $(n=$ 18). The $x$-axis error bars represent coefficient of variation for the source area (i.e., Ap horizon of the field) AAAc-P concentration, and the $\mathrm{y}$-axis error bars represent standard error of the average flow-weighted DRP concentration.

and drainflow, respectively. The values did not differ from each other, as shown by the $t$-test probability-value of 0.3089 . The combined (surface and subsurface DRP, $n=54)$ AAAc-P vs. DRP slope estimate had a value of $17 \mu \mathrm{g} 1^{-1}$ (SE $=1.7$ and a probability-value less than 0.0001 ), and $64 \%$ of the variation in DRP was accounted for. The slopes of the AAAc-P vs. Pw (for the Kokemäenjoki basin soils) and AAAc-P vs. DRP (for the combined L. Rehtijärvi data) was not found to differ from each other, the $t$-test probability-value being 0.0574 . The abundance of relatively low soil P levels in the L. Rehtijärvi catchment - most soils falling into the 'somewhat poor' category in the plant $\mathrm{P}$ supply point of view - resulting in a clearly skewed STP distribution (Fig. 3 and 4), however, restricts our possibility to make any definitive statements of the slope estimates. As compared to STP vs. DRP in drainflow, the apparently higher correlation between STP and DRP in surface runoff was probably a result of an even more skewed distribution in the latter.

The DRP concentrations measured in surface

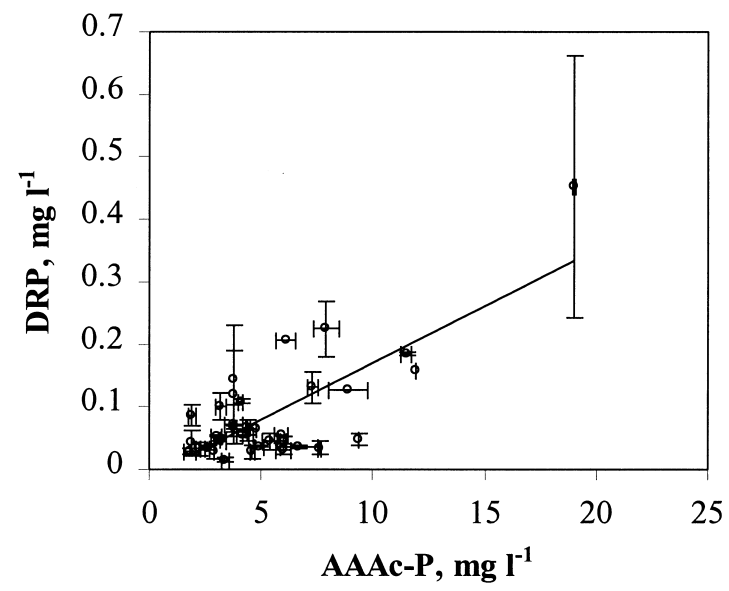

Fig. 4. Concentration of dissolved reactive $P(D R P)$ in subsurface drainage water at the L. Rehtijärvi catchment as a function of soil test $\mathrm{P}$ concentration (AAAc-P) in phoughlayer $(n=36)$. The $\mathrm{X}$-axis error bars represent coefficient of variation for the source area (i.e., Ap horizon of the field) AAAc-P concentration, and the y-axis error bars represent standard error of the average flow-weighted DRP concentration.

and subsurface runoff at the L. Rehtijärvi catchment had a wide within-site variation, as well as, variation between different sites with comparable STP values. For the individual samples collected during 1994-1996, a typical within-site variation in DRP concentration was 10 -fold, almost 80 -fold variation $\left(0.002-0.158 \mathrm{mg} \mathrm{l}^{-1}\right)$ being the maximum. The variation in average flowweighted DRP concentration in runoff between all study sites was about 30-fold (0.015-0.452 $\mathrm{mg} \mathrm{l}^{-1}$ ) and for the sites associated with AAAc-P concentrations of 2-5 $\mathrm{mg} \mathrm{l}^{-1}$ (these STP corresponded to $65 \%$ of the fields of this study) average flow-weighted DRP varied 10-fold (0.015$0.145 \mathrm{mg} \mathrm{l}^{-1}$ ). Given such a large variation in DRP concentrations, certainly owing to a number of factors, a question arises how confident would the soil test-based estimates of typical DRP concentration be, even in a small and a relatively uniform catchment as studied here.

For the purpose of studying how the STPinferred DRP estimates corresponded to the observed (long-term average) DRP concentrations, we used the Pw concentrations calculated for the 
Vol. 11 (2002): 343-353.

Kokemäenjoki basin soils $\left[\mathrm{Pw}\left(\mathrm{mg} \mathrm{l}^{-1}\right)=0.021\right.$ $\times \operatorname{AAAc}-\mathrm{P}\left(\mathrm{mg} \mathrm{l}^{-1}\right.$ soil $\left.)-0.015\left(\mathrm{mg} \mathrm{l}^{-1}\right)\right]$ as a proxy for the predicted DRP concentration. This was considered possible because the $t$-test suggested that the slope estimate of the combined data (AAAc-P vs. surface and subsurface DRP) did not differ from that obtained for the Kokemäenjoki basin soils (AAAc-P vs. Pw). In addition, all of the slope estimates were fairly close to each other and, after all, there are no other independent (AAAc-P vs. DRP) data sets available for this purpose.

In Fig. 5, the observed flow-weighted mean DRP concentrations (both surface and subsurface runoff) that were subtracted from the predicted $(\mathrm{Pw})$ values are plotted against the prediction. The deviation between the predicted values and the measured flow-weighted average DRP concentrations in runoff was $0.144 \mathrm{mg} \mathrm{l}^{-1}$ at maximum. In all but three sites, thus in about $95 \%$ of the cases, the deviation fitted into a prediction envelope of $\pm 0.10 \mathrm{mg} \mathrm{l}^{-1}$. Averaged over all of the 54 Rehtijärvi ditches and drains, the prediction deviated about $20 \%$ from the measured average DRP concentrations. There was, however, a clear tendency for the deviation to increase with predicted DRP concentration and a trendline fitted to the data plotted in Fig. 5 (Deviation = $\left.0.21 \times \mathrm{DRP}-0.003 ; \mathrm{r}^{2}=0.11\right)$ had a slope with a probability-value of 0.0147 .

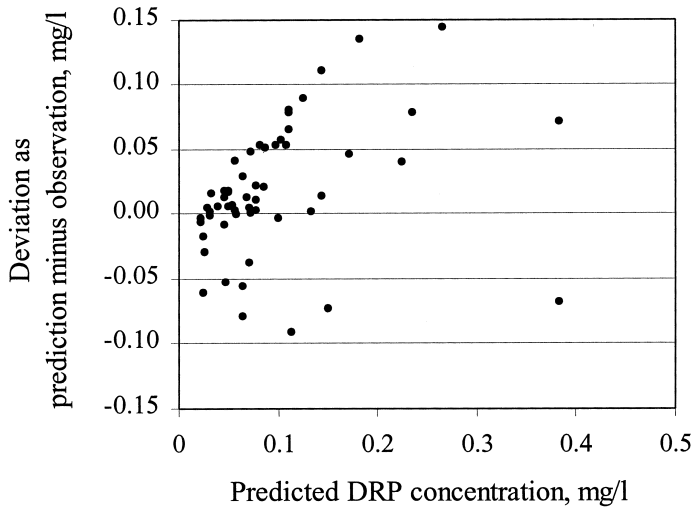

Fig. 5. The graph of deviations for the average flow-weighted concentration of dissolved reactive P (DRP) in surface and subsurface runoff at the L. Rehtijärvi catchment ( $n=$ 54); prediction is based on the relatioship presented in Fig. 2. [For a more detailed discussion of the method used, see Mitchell (1997)].

For the 397 individual runoff samples studied, particulate $\mathrm{P}(\mathrm{PP})$ was the major $\mathrm{P}$ form in runoff, with an average share of $76 \%$ of $\mathrm{TP}$ (range 8-99\%, median 81\%). Because this dominant $\mathrm{P}$ form was clearly dependent on the TSS concentration in runoff (Fig. 6), a comparison between AAAc-P and runoff TP concentration was not considered meaningful. For turbid runoff samples, Uusitalo et al. (2000) suggested that TP vs. TSS relationship, instead of TP concen-
Fig. 6. Relationship between total suspended solids (TSS) concentration and particulate $\mathrm{P}(\mathrm{PP})$ concentration in individual runoff samples. Data drawn for selected ditches and drains at the L. Rehtijärvi catchment.

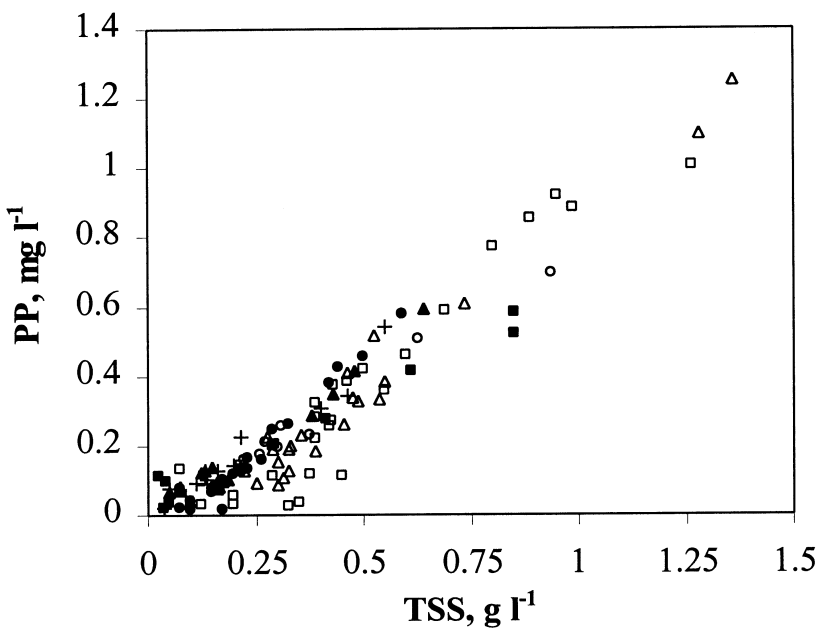

- $1 \mathrm{~S} 4$

$\Delta$ 1S5

$\circ 2 \mathrm{~A} 3$

- 2A5

$\triangle 3 \mathrm{~A} 8$

- $3 \mathrm{~S} 15$

$+5 \mathrm{~A} 2$ 
Uusitalo, $R$. \& Jansson, $H$. Dissolved reactive $P$ in runoff

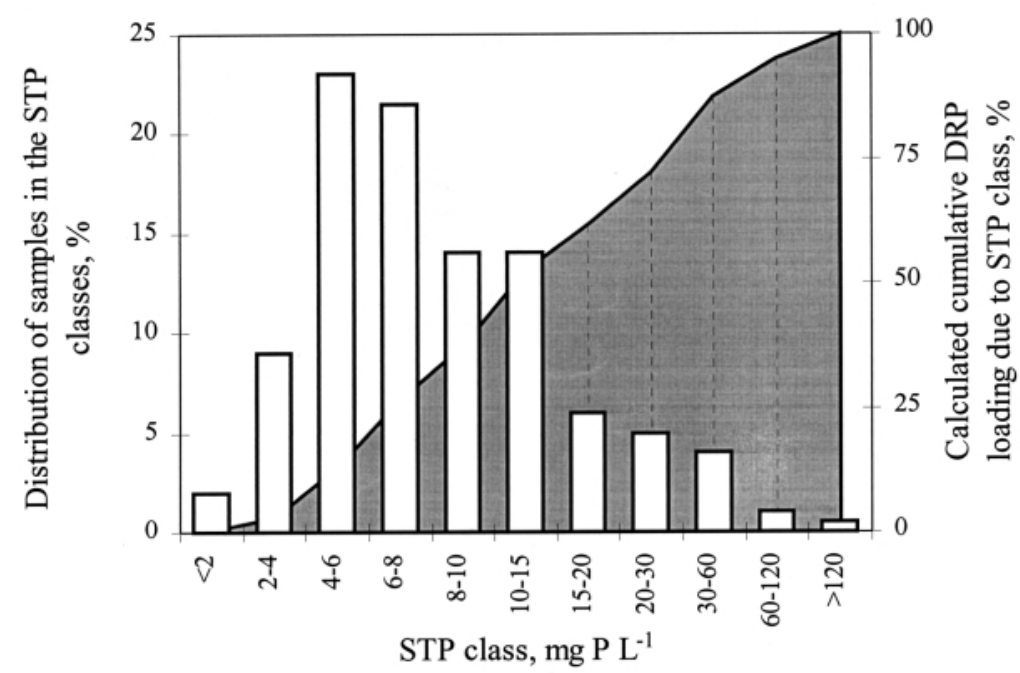

Fig. 7. Relative distribution of the about $0.5 \times 10^{6}$ samples of mineral soils analysed by Viljavuuspalvelu Oy during 1995-1998, divided into soil test P classes (bars, class limits represent ammonium acetate-extractable $\mathrm{P}$ in $\mathrm{mg}^{-1}$ soil). The shaded area represents the calculated (see text) cumulative loading potential of dissolved reactive $\mathrm{P}$ (DRP). tration, could be used for identifying soils with high $\mathrm{P}$ loss potential. In the L. Rehtijärvi data, the highest TP/TSS ratio $\left(1820 \mathrm{mg} \mathrm{kg}^{-1}\right.$ ) was addressed to the soil having the highest average STP concentration, but otherwise there was no clear trend in TP/TSS that could be explained by STP (not shown). With a TP/TSS range between 490 and $1820 \mathrm{mg} \mathrm{kg}^{-1}$, and an average of about $1000 \mathrm{mg} \mathrm{kg}^{-1}$, this ratio had a surprisingly wide variation, possibly reflecting variation in $\mathrm{P}$ sorption components in different parts of the catchment.

As stated earlier, most of the soils in the Rehtijärvi area tested low in $\mathrm{P}$ and $80 \%$ of the fields were associated with a soil AAAc-P concentration of $8 \mathrm{mg} \mathrm{l}^{-1}$ or less, with an agronomic interpretation 'satisfactory' or poorer. The STP concentration of the rest of the sampled hectares varied between 9 and $66 \mathrm{mg} \mathrm{l}^{-1}$. If we assume that the likelihood for runoff to enter the lake would be the same for all of the fields in this small effectively tile-drained catchment and if we use the same equation as earlier (from Fig. 2), the edge-of-field DRP loss potential (i.e., predicted Pw weighed by STP frequency distribution) would be as big for the about 185 ha with STP of $8 \mathrm{mg} \mathrm{l}^{-1}$ or less as for the about 35 ha testing 9-66 mg $\mathrm{l}^{-1}$ AAAc-P. In other words, less than $20 \%$ of the high P testing soils could be re- sponsible for producing as much DRP loading as the remaining $80 \%$ of the fields having AAAc$\mathrm{P}$ values of $8 \mathrm{mg} \mathrm{l}^{-1}$ or less.

An unpolished assessment of the previous kind can also be scaled up to whole of Finland if we assume that the AAAc-P vs. Pw relationship is roughly independent from the soil type (as suggested by the laboratory study) and the distribution of the samples falling into the different STP classes is independent from the P transport factors, that determine whether the risk for $\mathrm{P}$ loss realises. For this purpose, we used the STP distribution of the about 0.5 million soil samples analysed during 1995-1998 by Viljavuuspalvelu Oy (the biggest soil testing laboratory of the country having about $90 \%$ market share; the data is discussed in Yli-Halla et al. 2001). Here (Fig. 7), we see that the situation is similar to the L. Rehtijärvi catchment: $50 \%$ of the DRP loss risk could be assigned to the field area that represents a minority of the agricultural soils.

\section{Discussion}

The laboratory data suggested that a linear model could be used to describe the relationship be- 
Vol. 11 (2002): 343-353.

tween AAAc-P and water-soluble P. The Kokemäenjoki basin soils of the laboratory study had widely variable chemical and physical properties, and were partly sampled from non-cultivated areas. There didn't seem to be any soil property (textural class, $\mathrm{pH}$, organic $\mathrm{C}$ ) that would have caused deviation from the general trend in AAAc-P vs. Pw relationship. Approximately linear relationships between Morgan's P (Maguire et al. 2001) and Vermont 1-P (Jokela et al. 1998, Magdoff et al. 1999) vs. P soluble in water or dilute $\mathrm{CaCl}_{2}$ solution have been described over a wide range of soils and STP concentrations, suggesting that all of these acetate tests are closely related to P intensity characteristics of soils.

At the predominantly clayey L. Rehtijärvi area, the measured average DRP concentrations in runoff had a surprisingly good match to those predicted by the equation obtained from the laboratory data, i.e., AAAc-P vs. Pw relationship, despite the wide within-site variation in DRP. The success in predicting flow-weighted DRP concentrations supports the view that AAAc-P can be used to estimate the DRP loss potential of soils (Turtola and Yli-Halla 1999). In addition, our results support the view that extraction of soil using wide water-to-soil ratio may be used to approximate DRP concentration in runoff from clayey soils of southern Finland (Yli-Halla et al. 1995), even though the predicted DRP concentrations in our data were somewhat higher than the observed ones.

Our data showed that runoff from a given area may in different samplings show very variable DRP concentrations, and it is evident that runoff sampling has to be intensive and extended over long periods if we wish to establish STP vs. DRP relationships in such a relatively narrow STP range as was measured in the L. Rehtijärvi catchment. We believe that in our case, when the average DRP concentrations were based on grab samples, additional indicators of water chemistry - for example based on applications such as ion exchangers to monitor water chemistry (Edwards et al. 1993) or chemical P analysis of ditch sediment that equilibrates with runoff (Jansson et al. 2000) - would have provided useful supporting information on the typical DRP levels.

The paramount importance of soil sampling that matches the soil layer interacting with runoff, discussed by several authors (e.g., Sharpley and Withers 1994, Nash and Murdoch 1997), is also to be stressed. As shown by Haygarth et al. (1998), the P concentration may in grassland soils decrease very sharply within a few centimetres depth. Consequently, the mismatch of the sampled soil depth and that actually being in contact with runoff may lead to very different DRP concentrations in runoff than would be predicted by soil analyses (see Turtola and Yli-Halla 1999). In the Ap horizon of annually ploughed soils, the $\mathrm{P}$ distribution is, however, more homogenous as compared to grassland soils. Based on the fact that almost all of the Rehtijärvi fields were annually ploughed, and supported by the reasonably good fit between the observed and predicted DRP, sampling the whole depth of the latest primary cultivation seemed to be satisfactory in our case.

Assuming a linear STP vs. DRP relationship, a unit's decrease at any STP level would result in as big a reduction in average DRP concentration and, hence, DRP losses. On the other hand, the labile $\mathrm{P}$ pool tends to decrease more rapidly in the high STP concentrations than in the low ones (Saarela et al. 1995, Yli-Halla et al. 2002). Thereby, when a $\mathrm{P}$ test that responds to soil $\mathrm{P}$ buffering is used, the most effective strategy for DRP loss reduction at the Rehtijärvi catchment would likely be based on measures that decrease the AAAc-P concentrations of the $20 \%$ of the fields testing higher than $8 \mathrm{mg}$ AAAc- $\mathrm{P}^{-1}$. A similar strategy could also be used in a national scale, based on the similar AAAc-P frequency distribution in the L. Rehtijärvi catchment and the Viljavuuspalvelu data.

In conclusion, we suggest that soil AAA-P concentration serves as an indicator for a soil's potential to contribute to DRP losses from agricultural fields to the water environment. The DRP losses may be especially important in areas where erosion is not a major concern. How- 


\section{Uusitalo, $R$. \& Jansson, $H$. Dissolved reactive $P$ in runoff}

ever, as a measure of easily desorbable P, AAAc$\mathrm{P}$ does not relate to $\mathrm{P}$ losses associated with eroded soil particles that may be the major $P$ form in runoff (Jokela et al. 1998). For that purpose, other types of soil tests may be suitable.
Acknowledgements. We warmly thank the laboratory staff of the MTT/Environmental Research for performing the soil and water analyses, and Aaro Närvänen and Ari Seppänen for sampling the soils and waters.

\section{References}

Daly, K., Mills, P., Coulter, B. \& McCarrigle, M. 2002. Modeling phosphorus concentrations in Irish rivers using land use, soil type, and soil phosphorus data. Journal of Environmental Quality 31: 590-599.

Edwards, T., Ferrier, B. \& Harriman, R. 1993. Preliminary investigation on the use of ion-exchange resins for monitoring river water composition. The Science of the Total Environment 135: 27-36.

Gardner, C.M.K., Cooper, D.M. \& Hughes, S. 2002. Phosphorus in soils and field drainage water in the Theme catchment, UK. The Science of the Total Environment 282-283: 253-262.

Gburek, W.J., Sharpley, A.N., Heathwaite, L. \& Folmar, G.J. 2000. Phosphorus management at the watershed scale: a modification of the phosphorus index. Journal of Environmental Quality 29: 130-144.

Haygarth, P.M., Hepworth, L. \& Jarvis, S.C. 1998. Forms of phosphorus transfer in hydrological pathways from soils under grazed grassland. European Journal of Soil Science 49: 65-72.

Heckrath, G., Brookes, P.C., Poulton, P.R. \& Goulding, K.W.T. 1995. Phosphorus leaching from soils containing different phosphorus concentrations in the Broadbalk experiment. Journal of Environmental Quality 24: 904-910.

Holford, I.C.R. 1980. Greenhouse evaluation of four phosphorus soil tests in relation to phosphorus buffering and labile phosphate in soils. Soil Science Society of American Journal 44: 555-559.

Jansson, H., Mäntylahti, V., Närvänen, A. \& Uusitalo, R. 2000. Phosphorus content of ditch sediments as indicators of critical source areas. Agricultural and Food Science in Finland 9: 217-221.

Jokela, W.E., Magdoff, F.R. \& Durieux, R.P. 1998. Improved phosphorus recommendations using modified Morgan phosphorus and aluminum soil tests. Communications in Soil Science and Plant Analysis 29: 1739-1749.

Kuo, S. 1990. Phosphate sorption implications on phosphate soil tests and uptake by corn. Soil Science Society of American Journal 54: 131-135.

Kuo, S. 1996. Phosphorus. Extraction with buffered alkaline solution. In: Sparks, D.L. (ed.). Methods of soil analysis: Part 3 - Chemical methods. Soil Science Society of America, Madison, Wisconsin, USA. p. 895-897.
Lee, Y.S. \& Bartlett, R.J. 1977. Assessing phosphorus fertilizer needs based on intensity-capacity relationships. Soil Science Society of American Journal 41: 710-712.

Lemunyon, J.L. \& Gilbert, R.G. 1993. The concept and need for a phosphorus assessment tool. Journal of Production Agriculture 6: 483-486.

Magdoff, F.R., Hryshko, C., Jokela, W.E., Durieux, R.P. \& Bu, Y. 1999. Comparison of soil test extractants for plant availability and environmental assessment. Soil Science Society of American Journal 63: 9991006.

Maguire, R.O., Foy, R.H., Bailey, J.S. \& Sims, J.T. 2001. Estimation of the phosphorus sorption capacity of acidic soils in Ireland. European Journal of Soil Science 52: 479-487.

McDowell, R.W. \& Sharpley, A.N. 2001. Approximating phosphorus release from soils to surface runoff and subsurface drainage. Journal of Environmental Quality 30: 508-520.

Mehlich, A. 1984. Mehlich-3 soil extractant: A modification of Mehlich-2 extractant. Communications in Soil Science and Plant Analysis 15: 1409-1416.

Mitchell, P.L. 1997. Misuse of regression for empirical validation of models. Agricultural Systems 54: 313326.

Murphy, J. \& Riley, J.P. 1962. A modified single solution method for the determination of phosphate in natural waters. Analytica Chimica Acta 27: 31-36.

Nash, D. \& Murdoch, C. 1997. Phosphorus in runoff from a fertile dairy pasture. Australian Journal of Soil Research 35: 419-429.

Saarela, I., Järvi, A., Hakkola, H. \& Rinne, K. 1995. Fosforilannoituksen porraskokeet 1977-1994. Vuosittain annetun fosforinmäärän vaikutus maan viljavuuteen ja peltokasvien satoon monivuotisissa kenttäkokeissa. Summary: Phosphorus fertilizer rate trials, 19771994. Effects of the rate of annual phosphorus application on soil fertility and yields of field crops in longterm field experiments. Maatalouden tutkimuskeskus. Tiedote 16/95. Maatalouden tutkimuskeskus, Jokioinen, Finland. 94 p. (In Finnish with English summary).

Sharpley, A.N. \& Withers, P. 1994. The environmentallysound management of agricultural phosphorus. Fertilizer Research 39: 133-146.

Soil Survey Staff 1998. Keys to Soil Taxonomy. 8th ed. 
Vol. 11 (2002): 343-353.

USDA Natural Conservation Services, Washington, DC. 327 p.

Tattari, S., Bärlund, I., Rekolainen, S., Posch, M., Siimes, K., Tuhkanen, H.-R. \& Yli-Halla, M. 2001. Modeling sediment yield and phosphorus transport in Finnish clayey soils. Transactions of the ASAE 44: 297-307.

Turtola, E. \& Yli-Halla, M. 1999. Fate of phosphorus applied in slurry and mineral fertilizer: accumulation in soil and release into surface runoff water. Nutrient Cycling in Agroecosystems 55: 165-174.

Uusitalo, R., Yli-Halla, M. \& Turtola, E. 2000. Suspended soils as a source of potentially bioavailable phosphorus in surface runoff waters from clay soils. Water Research 34: 2477-2482.

Valpasvuo-Jaatinen, P., Rekolainen, S. \& Latostenmaa, H. 1997. Finnish agriculture and its sustainability: environmental impacts. Ambio 26: 448-455.

Vuorinen, J. \& Mäkitie, O. 1955. The method of soil testing in use in Finland. Agrogeological Publications 63: $1-44$.
Yli-Halla, M., Hartikainen, H., Ekholm, P., Turtola, E., Puustinen, M. \& Kallio, K. 1995. Assessment of soluble phosphorus load in surface runoff by soil analyses. Agriculture, Ecosystems and Environment 56: 53-62.

Yli-Halla, M., Hartikainen, H. \& Väätäinen, P. 2002. Depletion of soil phosphorus as assessed by several indices of phosphorus supplying power. European Journal of Soil Science 53: 431-438.

Yli-Halla, M. \& Mokma, D.L. 2001. Soils in an agricultural landscape of Jokioinen, south-west Finland. Agricultural and Food Science in Finland 10: 33-43.

Yli-Halla, M., Nykänen, A., Siimes, K. \& Tuhkanen, H.-R. 2001. Ympäristötuen ehdot ja maan helppoliukoisen fosforin pitoisuus. Abstract: Agri-Environmental Programme regulations and the easily soluble phosphorus concentration in soil. MTT publications. Series $A$ 77. MTT Agrifood Research Finland, Jokioinen, Finland. 45 p. (In Finnish with English abstract).

\title{
SELOSTUS
}

\section{Viljavuustutkimuksen fosforianalyysi valumavesiin liuenneen fosforin pitoisuuden kuvaajana}

\author{
Risto Uusitalo ja Håkan Jansson \\ MTT (Maa- ja elintarviketalouden tutkimuskeskus)
}

\begin{abstract}
Neuvonnallisessa maa-analyysissä käytetyt fosforin uutot voidaan jakaa karkeasti niihin, joilla arvioidaan maan helppoliukoisen fosforin pitoisuutta ja niihin, joilla arvioidaan pitkän ajan kuluessa kasvien käyttöön vapautuvan fosforin kokonaismäärää. Maan helppoliukoiset fosforivarannot ovat keskeisiä pellolta valuvaan veteen liukenevan fosforin kannalta. Suomessa käytössä olevalla maa-analyysimenetelmällä, uutto happamalla ammoniumasetaattipuskurilla, arvioidaan juuri helppoliukoisia fosforivarantoja, ja teoreettiselta kannalta kansallinen menetelmämme saattaa siten soveltua valumavesien liuenneen fosforin pitoisuuden ennustamiseen. Tässä työssä tutkittiin happamaan asetaattiliuokseen uuttuvan fosforin määrän (maa-analyysin fosforiluku) ja veteen liukenevan fosforin välistä yhteyttä laboratoriossa ja peltokokeessa.
\end{abstract}

Laboratoriossa maa-analyysin fosforiluku ja veteen liukenevan fosforin määrä olivat selkeästi yhtey- dessä toisiinsa, eikä maan orgaanisen hiilen pitoisuus, maan happamuus tai maalaji vaikuttanut tähän yhteyteen. Jokioisten Rehtijärven valuma-alueella (pääosin hiuesavimaita) tehdyissä kenttämittauksissa maa-analyysin fosforiluvun ja valumavesiin liuenneen fosforin keskimääräisen valumapainotteisen pitoisuuden välillä havaittiin lähes samanlainen yhteys. Valumavesien liuenneen fosforin keskimääräinen pitoisuus voitiin $95 \%$ tapauksista ennustaa $\pm 0,10 \mathrm{mg} / \mathrm{l}$ tarkkuudella laboratoriokokeista saadun yhtälön avulla. Yhtälö hieman yliarvioi liuenneen fosforin pitoisuutta peltovalumavesissä, erityisesti suuremmissa fosforipitoisuuksissa. Puolet Rehtijärven valuma-alueella liuenneen fosforin huuhtoumasta saattaa tulla ainoastaan $20 \%$ viljelyalalta. Viljavuuspalvelussa vuosina 1995-1998 tehtyjen määritysten fosforiluvun jakauman perusteella tilanne saattaa olla samankaltainen koko maassa. 